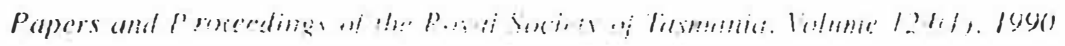

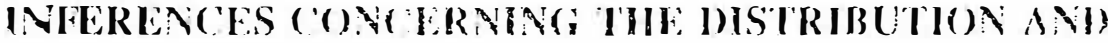

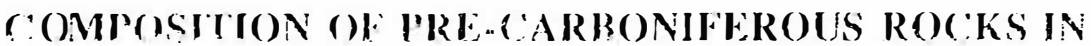 SOUUILISIFIRN IASMANIA
}

\author{
bi 1) 1 ! I cilina!n \\ (x) it! genen loxi liones)
}

I.L:AMAN, 1 I:.. 199()$(31: \ldots)$ : Inferences concerning the distribution and composition of pre-Carboniferous rocks in southeastern Tasmania. Pap. Proc. R. Soc. Tasm. 124(1): 1-12. https://doi.org/10.26749/rstpp.124.1.1 ISSN 0080-4703. Leaman Geophysics, GPO Box 320, Hobart, Tasmania, Australia 7001.

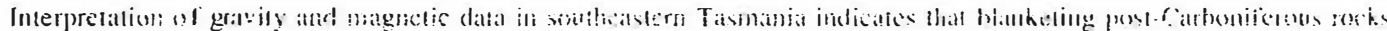

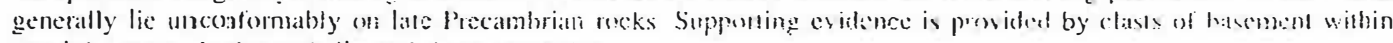
overlying pyrnclastics and till, and ther horelicks

Near Hobart, west of the Huon River and south of Brany Istand, deep troughis were lilled with (?) Cimbrian seepuentes with a significan volcanic component. Some whramafics are presesll along lhe western margins. Robanively thin uedges

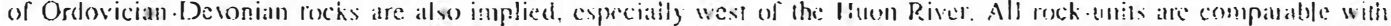
those exposed in vestern Tasmania.

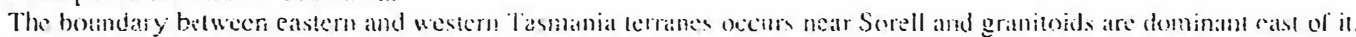

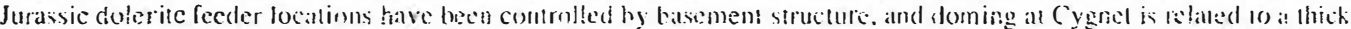

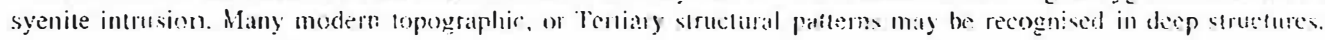

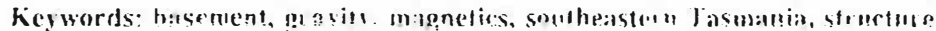

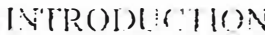

Southeastem Tasmania is dielined here as the area south of the batilucle of New Norfolh ard ands ol this longitude of the piston River (fig. 1). Thi surfice geology is dominaled by exproutes of Permo Triassic Parmeener Supergroup rocks am Jumasie dolerite. Ninor intmsions of ('retareous ienents rocks oceur near Cygnel, and lentiary volcantes and sediments are also present. much of the falto is ing beneallh the waters of Shom Baty and the toment estuary.

Pre-Carloniteroms rents are larely exprosed and

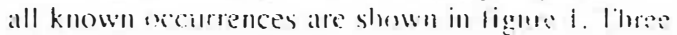

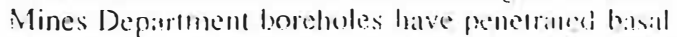

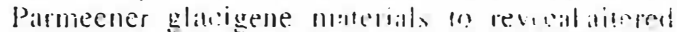

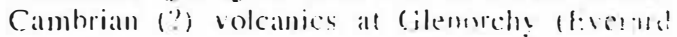

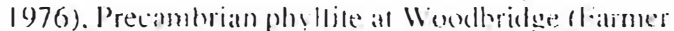
\& Clarhe 148.5) and comlact-melalumorphosed

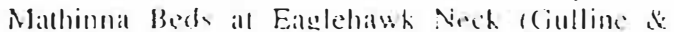
Clarke 198t). An exemsion of. or splay lom lhe

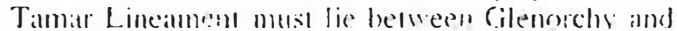
Pirates Baly. in (roder lo arconum for juxtaporition al bascments of westem and easiern lasmanial

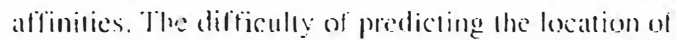
this junction wats stressiol by Williams (1976). The

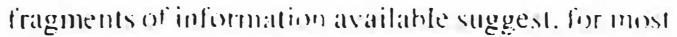

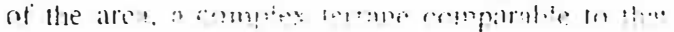

e) posed in morhern and westem Tasmania. Kunmedelge and molerstanding of it may well have ramifiantions for mineral or perolenes exploralion. A small peroledem exploter, Congal ()il. acepuired airborne matgnedis dalla aleross the regegon and infilled parts of the state gravity data hatse doring 1987. The atbihon was engaged o interpret this data in terms ol

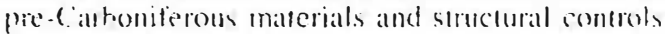
and, in pardicular, to identify siles which migh entain ()ridon jeian Gordon (iromp). Carbonalles of this group are believed a have somered miner oil seppages in the region of Bramy lalames.

This papter reports courient understanding af pro. (arhoulderous matsials balsed on that interpretalion

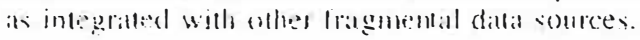

\section{(iFO) OOCHCAL DAlA}

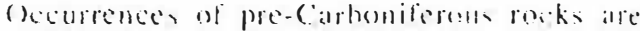

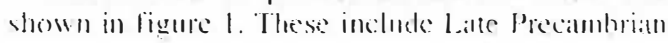
recks near Hastings and alomg He Hold River. Cambrian voleanics alonge the somth colast. and ( )iclowician Cordon (iroup carhomales all Nell River. alung the Picton Rives. all Icla Baly and al Haslings. Devomian Eranile, of eastern Tasmantil affinity. necuss near Piralles Bay. Cambrian (?) malic and

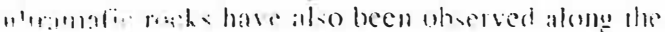




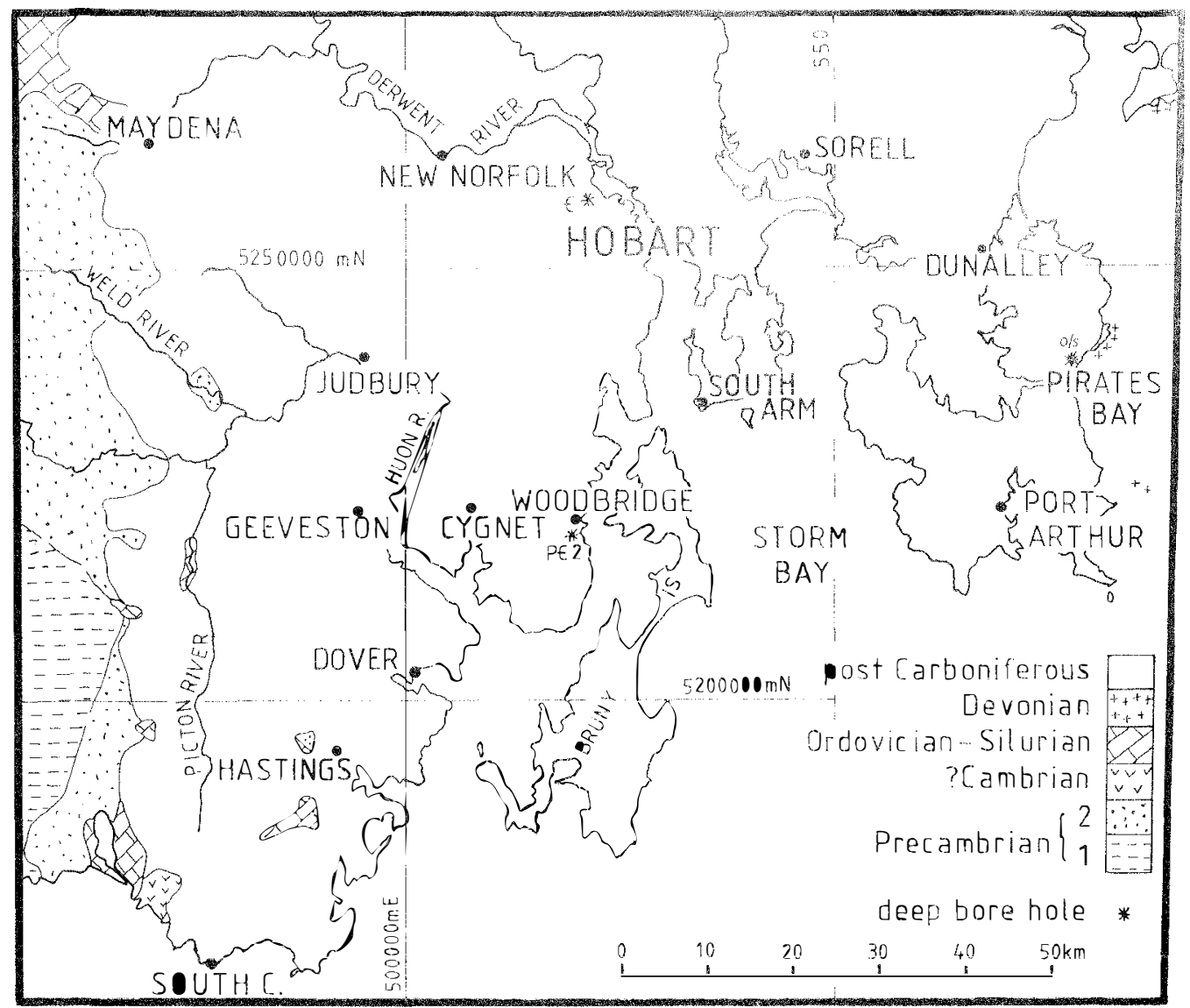

FIG. I - Locality map for southeastern Tasmania. All known exposures of pre-Carboniferous rocks are shon'n.

Weld River (T. Summons, K. Morrison, pers. comm.). Altered Cambrian volcanics occur at $600 \mathrm{~m}$ depth at Glenorchy (Leaman 1972. Everard 1976) and Precambrian phyllite underlies Truro Tillite at $998 \mathrm{~m}$ depth at Woodbridge (Farmer \& Clarke 1985). The boreholes suggest minimum depths to pre-Carboniferous matcrials since the sites were specially selected. Another hole, at Cygnet, was abandoned after proving a tillite thickness in excess of $450 \mathrm{~m}$ (Farmer 1985). A hole at Eaglchawk Neck (Gulline \& Clarke 1984) encountered a Mathinna Bedsadamellite contact at $398 \mathrm{~m}$.

Basal Parmeener Supergroup formations are rarely exposed within the region and there are few opportunities to consider provenance of their contents. Although no rigorous study of the pebble compositions within the Truro Tillite has been completed at, or between, available exposures. Leaman \& Naqvi (1968) and Banks (1981) have tabulated information on clast compositions. The tillites at Woodbridge and Cygnet are anomalous in a Tasmanian context; they are rich in igneous and Precambrian metamorphic material whereas clasts of many Palaeozoic sedimentary rock types, including limestone, are present but relatively rare. This anomalous enrichment implies passage of the ice sheet across a metamorphic terrane, winnowing. and/or a local predominance of such rock types, since it is known that the deposits are irregular and fill depressions in the Carboniferous topography. No tillite was found in the Glenorchy bore. In these conditions it might be expected that local rocks. 
within a radius of $10-50 \mathrm{~km}$, migh have lod ment of the basal units. The mplied provenance of the tills at Woodbridge and Cygnot is also whally consistent with the known rock types at depth, or exposed west of the Picton River yaydona Buon so, the lack of pebbles of palmonit whmory rocks is abnormal, given he molve momman recorded elsewhere, the guncal distribution of

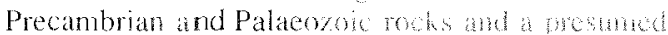
ice movemen from the west on nowhes (Ctake 1988). These anomalies may inticale a very bow less than $20 \mathrm{~km}$, derivation and lack of Patuewont sedimentary rock exposine to the ice shot. This scale of source range was suggested by banks (1981) for material at Maydena but cannot be verified in the region southeat of Maydena due to lack of exposure.

It may be argued that clast confent of tills several hundred metres above their base is not a reliable indicator of provenance or local basement. The relief of the filled terrain is comparable, however, with the horizon levels sampled and this is probably not a critical objection.

Pyroclastic rocks offer an altemative sampling of basement rocks. Few mappers, however have recorded ejecta compositions and, unfortunately, most Tertiary volcanic activity is restricted to the region east of the D'Entrecasteaux Channel and Mi Wellington. Contents of some volcanic centres have been described by Sutherland (1976), Leaman (1976) and Famer (1985). Some other centres have been inspected by the writer. Fragments of Parmeener Supergroup rocks or dolerite are common, athough proportions vary at each vent. Only two sites inspected to date, at Acton and Risdon east of Hobart, present distinctive amounts of any other material - - a quartz-veined phyllite comparable to basement in the Woodbridge bore. These observations can be considered definitive and representative of basement east of Hobart.

Although sampling by volcanoes or drilling is limited, it does suggest that exposures at Weld River and Hastings may be typical of pre-Carboniferous basement in southeastern Tasmania -.... Precambrian rocks but not of the Tyennan region (Tumer 1988). This accords with the more ambiguous implication based on tillite clast observations.

\section{GEOPHYSICAL DATA}

Seismic, magnetic and gravity data are available for large parts of southeastern Tasmania.

The seisnic method, potentially very informative, is of limited value due to energy transmission and processing problems Muct research will be required before generally acceptable results are achievable. Most of the region south of Tasman Peninsula, including Stom Bay, was surveyed by Amoco (Amoco 1971). Water bepth and character in Kecen and Terbary stimens and sebmontary rocks are clearly prosened Seimic basement, usually doleric or Pewran rocks, is cheountered at

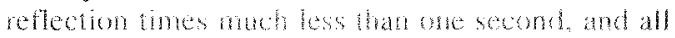
seismie reords are thenter degated the base of tho Pameener semergup is never recognised, nor is the base of any dolerite shees. In each case the large velocty densily (acoustic) contrast should generate a shong refocton. Similarly disappointing results appear to have becn recorded duning a recent survey by the Bureat of Mineral Resources during 1988 (P. Hill, pers. comm). Onshore surveys present porer source receiver transmission conditions but yield similar results (e.g. Leaman 1978, Leaman \& Richardson 1981). Most energy appears to be reflected by the uppermost dolerite surface with production of a seismic shadow. However, Leaman (1978) was able to find rare sites in which good rellections wore recoverable from the surface to Woho depths. A site near Clifion, on South Arm, suggested that either the problems were not intractable or that different conditions applied.

Conga Oil reconded a test line on North Bruny Island during 1987; the results were consistent with previous surveys, True reflection character was barely discernible at about 0.4 and 2 seconds respectively. The remainder of the record was typical of noise or homogeneous non-reflective material. At the velocities observed, the upper character change might represent the sub-Parmeener unconformity.

Results such as that noted at Clifton suggest that the method is either generally unworkable south of Hobart, for various reasons, or that deep reflectors are generally absent. The second explanation would imply that post-Cambrian sedimentary rocks (Cordon Group for example), which are heterogeneous and contrasting in propertics and would present strong acoustic contrasts, are not common. Further wesarch is necessary before this judgment can be refined or molified.

The potential field methods, gravity and magnetics, offer the best opportunity for regional appraisal. Four regional magnetic surveys have been completed in the area (Finney \& Shelley 1967, Esso 1967. Leaman 1987, BMR 1988). Only that undertaken by Conga Oil (Leaman 1987 ) is fully defined and suitable for detailed analysis. It also covers onshore and offshore segments of the region. 


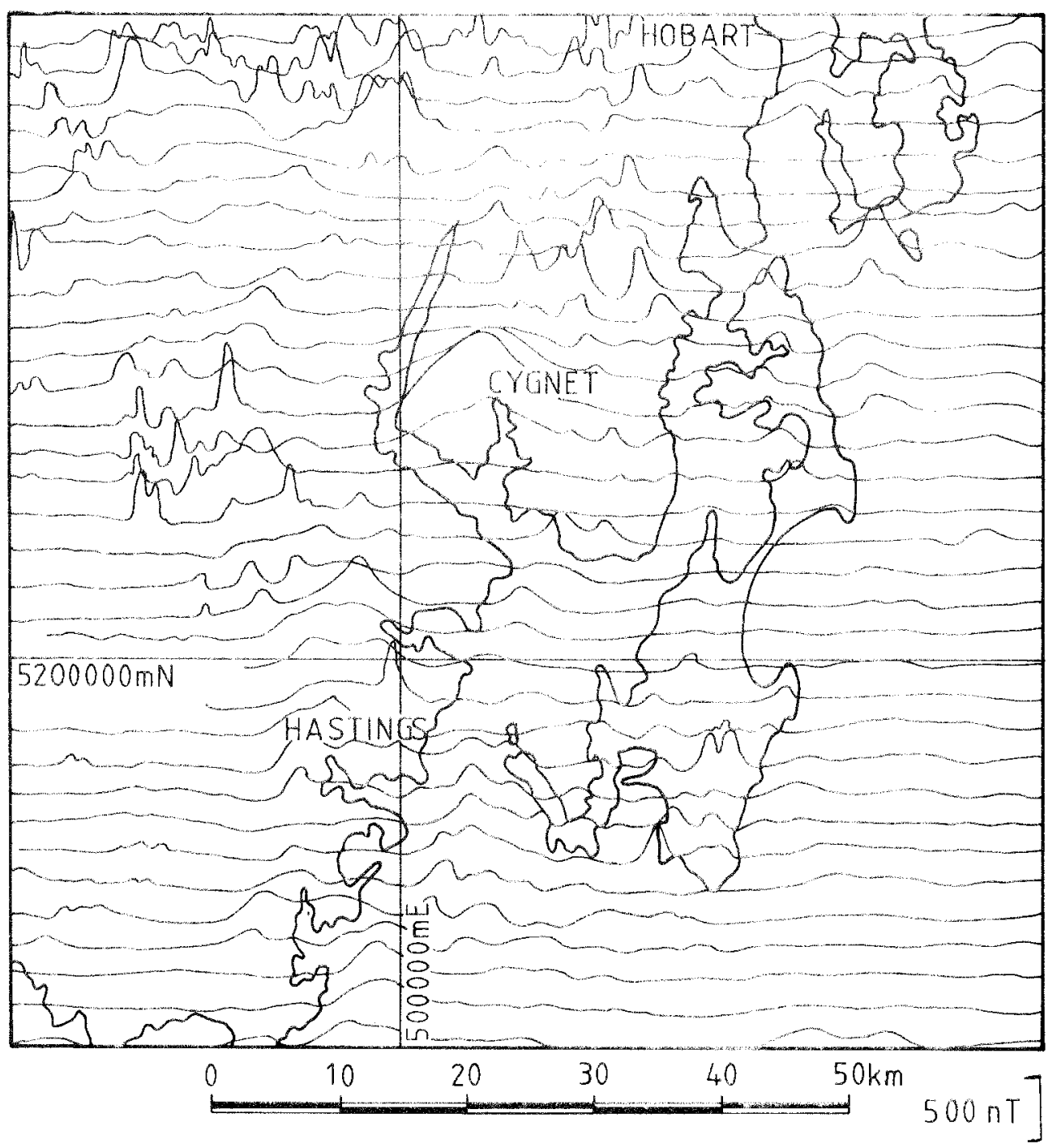

FIG. 2 - Magnetic profiles, $2.5 \mathrm{~km}$ apat, observed at $1000 \mathrm{~m}$ abose sea level. The large Cygnet anomaly and tracts of magnefic hasement are indicated by raised field intensity lesets. Most high frequency character reflects delerite capped topography. Survey for Conga Oit.

Prolites of the magnelic field are shown in figure 2 . The field was observed at an elevation of $1000 \mathrm{~m}$ a.s.l and is generally free of any flight deviations. The figure stresses the characteristics of the magnetic field. Some areas contain large isolated anomalies, others extensive regional sources. Since the average terrain clearance was in excess of $700 \mathrm{~m}$ for most of the survey, only large. deep-seated or verically exterided somens are reflected in the data.

The gravity data base of Richardson \& Leaman (1987) was infilled by Conga Oil to a variable but nominal station spacing of $2 \mathrm{~km}$. The Bouguer map produced was compared to the state crustal model (MANTLE-88, Leaman 1988a, Leaman \& Richardson 1989); the resulting residual anomalies are shown in figure 3. These reveal a broad belt of 


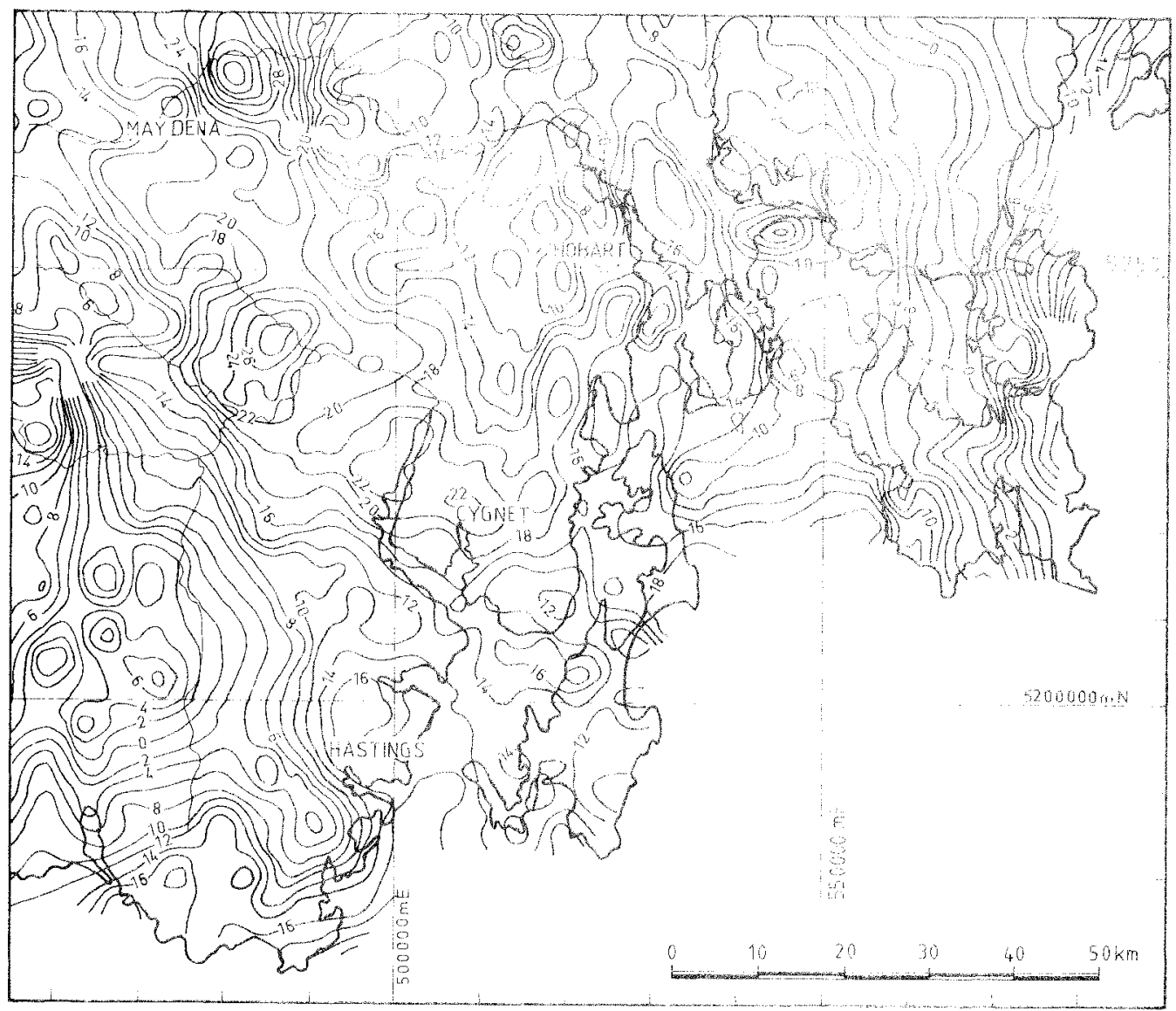

FIG.3-Residual Bouguer anomalies derived from observad Bonguer anomaliesseduced at a dentwity of 2.67

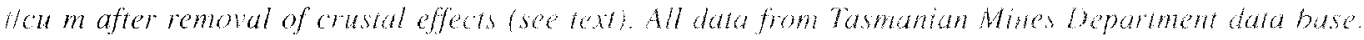

positive anomalies extending northwest from tht Huon estuary.

Although trend information can be deduced lown ligures 2 and 3. or variations of then, cach data set requires extended analysis before delails on basement strucure can be described mably.

\section{GRAVITY MAGNETIC INTERPRETATIOKN}

Complete interprelive detals and discussion are given by Leaman (1987) and only conclusions or eritical aspects are presented here.

Quantitative nodelling of both data sels was based on a N-S, E, W, NW-SE and SW-NL array of 17 interlocking profiles, and the solutions acepted were based on consistont profle natehes and criteria for an data. Relability of the interpretation is uniform somb of $5255000 \mathrm{~min}$

figure 2 suggest tha two distine magnetic

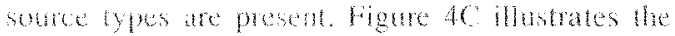

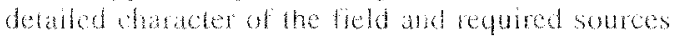
and shows that the basic form of the profle is satistied by a boad deep, basintlke somec of moderate comast Spiky etenems releot mote local and shlower sources The large spike doublet is pare of the Cygnet anomaly (seefig. 2). The general response of the primary seurce is governed by its bulk contras, depth range, masginal dips and depth to its upper suthes. The depth range factor is least strsitive but must exced 5-6 km. High frequency coments are related to bolonte or, exceptionally, 


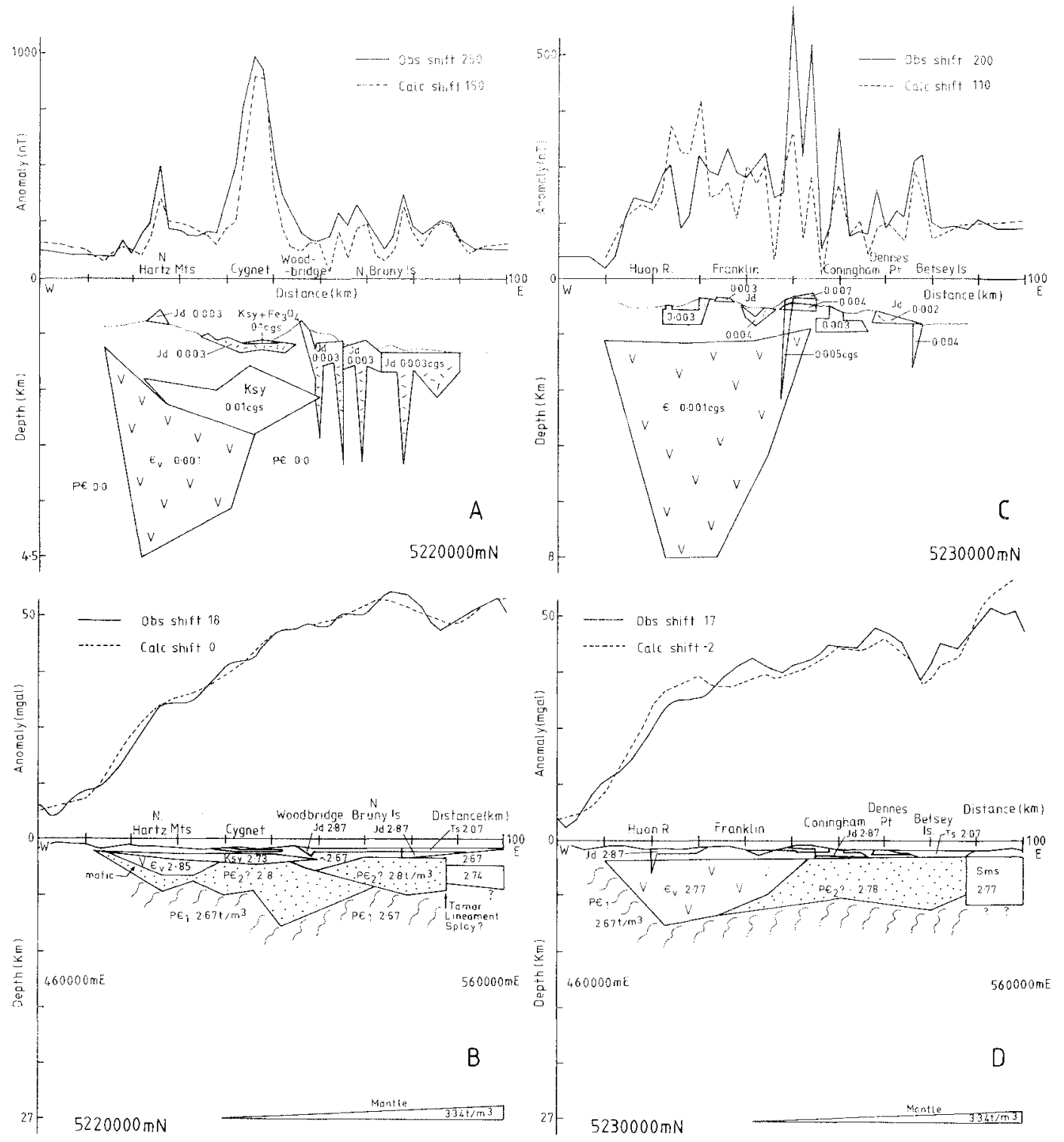

FIG. 4-Typical magnetic and gravity interpretation models. (A, B) for E-W line at $5220000 \mathrm{mN},(C, D)$ at $5230000 \mathrm{mN}$. Symbols: Ts, Tertiary sediments; Ksy, Cretaceous syenite; Id, Jurassic dolerite; Sms, Silurian Mathinna Beds; $D g$, Devonian granite; Ev, Cambrian volcanic suites; $p E_{2}$, Jubilee region style Precambrian; $p E_{j}$, Tyennan region style Precambrian. 
syente (below). Only major changes in source geometry, especially those with sub-vertical aspects, can yield the field character observed after filtering by large terain clearances. The precise character of each response is not easily reproduced by simple lwodhmonstal nodelleng but the style is defnitive velcling of all profiles selected has shown that manete character is either of this binary lype, large the deep sources with local shallow sources, or sinply of the small source type.

Large, deep sontres are restricted to distinct zones. Modelling also verifies that the marked, isolated anomalies, or spikes, evident in ligures 2 and 4 are related to large dolerite dykes or feeder pipes with vertical ranges of at leasi $2 \mathrm{~km}$. Only a small part of the observed responses an be associated with property or contrast change such as induced by the presence of granophyric or other extreme differentiates; the geometric factor is paramount.

Figure $4 \mathrm{D}$ presents the equivalent gravity solution. Some potenilally ambiguous elements are minimised or resolved by the magnetic information. The gravity models of figure $4 \mathrm{~B}$ and $\mathrm{D}$ are based on the observed, not residual, Bouguer anomalies and the crustal asper of the model is therefore included.

The large magnetic anomaly centred on Cygnet has long been known and always assumed to be associated with the Cretaceous syenite complex (e.g. Finney \& Shelley 1967, Leaman \& Naqui 1968) although the mecise origin has been debated. The anomaly correlates with a domal structure in the Cygnet region. Regional modelling of typical profiles shows that the Cygnet anomaly also has two source components; one near surface and of extreme contrast and another of large volume and moderate contrast at moderate depth. The near-surface source is volume limited and consistent with the alteration products, including free magnetite and pyrrhotite observed around Port Cygnet. The deeper source extends northeast toward Woodbridge, as does the yenite dyke swam.

Figure $4 \mathrm{~A}$ suggests the magnitude of the source. A accolithic syenite pod $750 \mathrm{~m}$ thick, with lateral ixtent suggested. emplaced at the base of the Truro Tillite, would be able 10 generate the doming sbserved around Cygnet. Such a pod also accounts for the anomalous regional metamorphism recorded by Leaman \& Naqui (1968) and Farmer (1985: 69). This new analysis shows that Leaman \& Naqui 1968) were correct in inferring a large laccolithic form but misplaced its location. Their use of the lerm hybrid for the alteration, especially of dolerite, south of Cyenet was misunderstood by Farmer (1985) who then failed to appreciate the significance of the metanomphism described. The roof of the laccolith may lie close 10 , or in the highly altered dolerite sheet exposed near Cygnet. The dyke swan pattern appears to reflect anisotropic extemsion of the roof rocks.

The equivalent arat profile (fig. $4 \mathrm{~B}$ ) in an

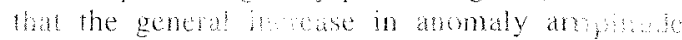

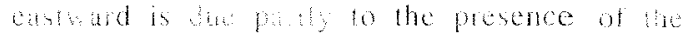
magnetic rocks, but the ellece is stistaned by nonmagnetic, derse materials further east. The crustal contribution is minimal on this line. The relationship between anomaly and exposed Tyennan region basement west of the Picton River suggests that wis lithology is representative of ultimate basement at a general depth of about $5 \mathrm{kn}$.

The combined analysis enables conversion of the magnetic field data (fig. 2) into a plan of dolerite feeder locations (fig. $5 \mathrm{~A}$ ), the reliability of which is limited only by survey specification. Most elements of dolerite intrusion form can be deduced from the two data sets, al though inferences based on only one data set can sometimes be misleading. The strong anomaly near Betsey Island, first noted by Flinders and marked on marine charts ever since, is due to a large feeder system.

Modelling has also established that the dense, magnetic sequence is only present in parts of the region. Figure 4 shows this to have the form of a deformed onlapped or rift trough fill. The upper surface is generally at a depth consistent with the base of the Permo-Carboniferous sequence after allowance for normal formation thicknesses. Although tillite estimates are uncertain it seems likely that the tillite or basal formations either overlie the magnetic units directly or are separated by less than $500 \mathrm{~m}$. Non-magnetic Gordon Group formations must be thin, if present. Although the magnetic sequence is not universally present, the response pattern can be traced to the south coast, where it is associated with exposures of mafic Cambrian units, or to Glenorchy, where altered (?) Cambrian volcanics were found to underlie Permian rocks. The principal belt of these presumed Cambrian rocks extends NW-SE from the Weld River to Hastings (fig. 2). The entire gravitymagnetic pattern is similar to that observed in western Tasmania, between the coast and the core of the Tyennan region east of the Birch Inlet- Elliott Bay axis, but as a mirror image (Leaman 1988b). The inferred rock properties are consistent with a predominantly mafic assemblage such as the Crimson Creek Formation and its correlates (Brown 1988). A secondary belt of such rocks extends from Cygnet toward Hobart but the greatest development lies south of Bruny Island. Review of the magnetic data from these volcanic sequences has shown that 


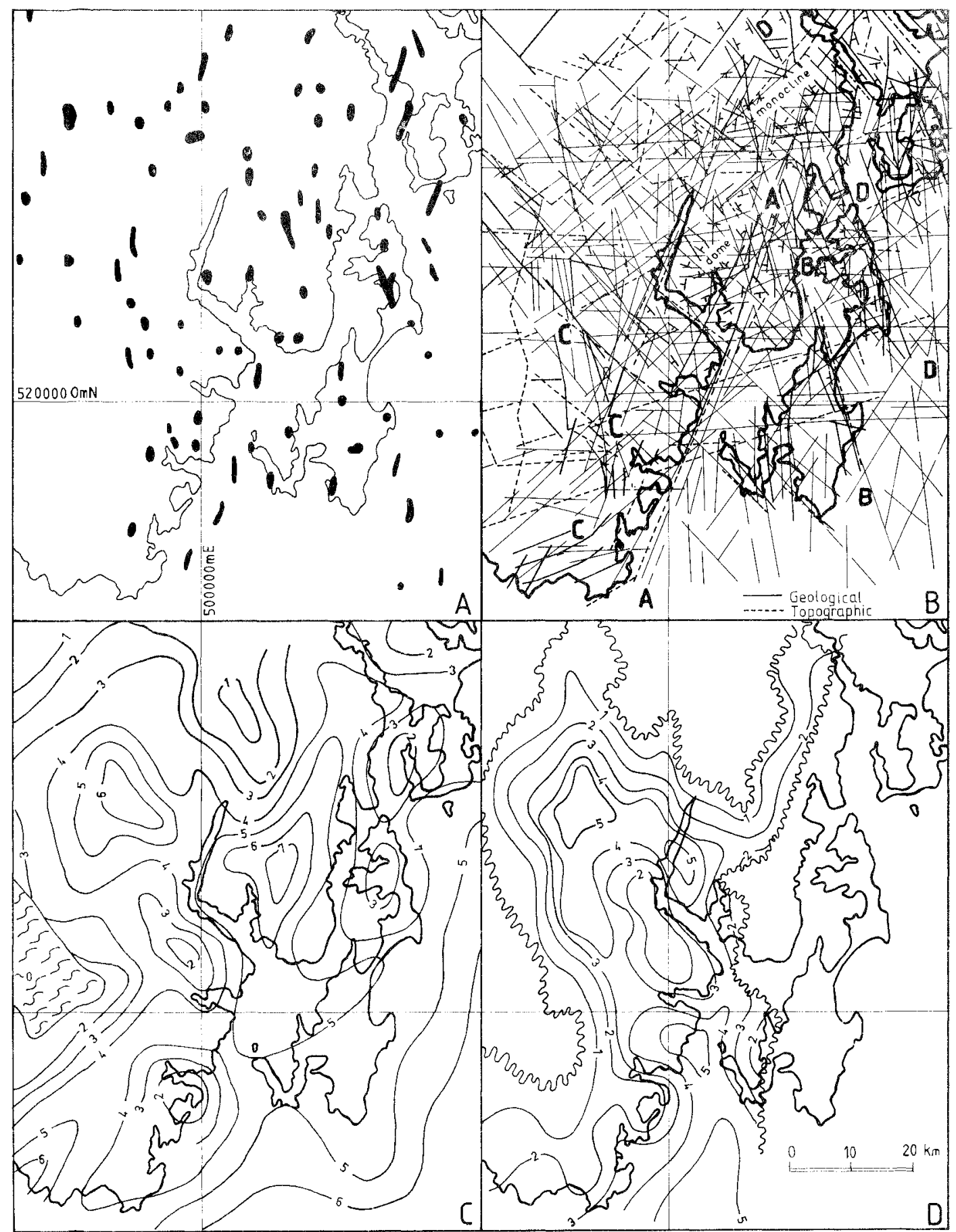


some localiti escontain materials with bulk contrasts consistent with ultramafics. These are restricted to the western side of the Huon trough axis west of Geeveston and also near the Weld River.

The remainder of the basernent is non-magnetic but quite dense, at least to depths of $3-5 \mathrm{~km}$, in much of the region. The non-magnetic basement properties can be traced eastward from exposures west of Maydena and northwest of the Picton River. The properties and patterns are consistent with an ultimate, siliceous Tyennan-region-style Precambrian basement, generally overlain by a Jubilee-region-style Precambrian basement, such as exposed near Maydena (Turner 1988).

Figure $5 \mathrm{C}$ and $\mathrm{D}$ summarise the interpretation in terms of Cambrian and Precambrian units. The trend patterns (fig. 5B), compiled from the data sets and post-Carboniferous structures to indicate frequency of recognition and importance, can be compared with old trough structures. Any differential between the upper surface of siliceous basement and the base of the volcanic units is a measure of the thickness of presumed Jubilee region rock types (also fig. 6). The relationships are similar to those observed or inferred in northwestern Tasmania (Leaman 1988b).

\section{DISCUSSION}

Several strands of evidence and information have been utilised to obtain an indication of the constitution of the concealed pre-Carboniferous basement in southern Tasmania. There is much scope for refinement.

The Tertiary, Cretaceous and Jurassic igneous rocks, while not strictly part of the topic of this paper, occupy some of the volume below the Carboniferous unconformity. It could also be expected that their emplacement has been at least partly controlled by older structures. For example, several large dolerite feeders lie near the eastern edge of the Cambrian belt from Ferntree to Red Hill and Garden Island Creek; so does the Cygnet alkaline intrusion. Compare figure 5A, C and D. Figure $5 \mathrm{C}$ clarifies an issue raised by Leaman (1972). The gravity field in the region of $\mathrm{Mt}$ Wellington was considered locally negative and not explained by known materials or possible deficiencies in terrain corrections. The observations were thought to indicate a granite stock in basement. which also forced subsequent extensional fracturing to pass around this region. A local basement ligh composed of siliceous Precambrian materials. with a relief of several kilonetres, surrounded or onlapped by a denser sequence would produce a similar ofect. It is also possible to speculate on the origin of the only zone in the Hobart district with easterly dips. This lies between the city and Mt Wellington and includes several junctions involving large Tertary and Jurassic movements, as well as overlying the pinched northem extension of the Cambrian trough. The dips may reflect a continuing process of rejuvenation of the old basement core bencath the Wellington tableland to the west (fig. 5C).

General inferences concerning the distribution and relationships of principal basement types are shown in figures 6 and 7. The basal Pernian or upper Carboniferous formations may generally overlie either Cambrian volcanics or Precambrian phyllites and units comparable to those of the Jubilee region. The gravity-magnetic interpretation is consistent with available pyroclastic and drilling data and the common seismic result. Nearly all seismic surveys have been undertaken where all the other methods imply a Precambrian basement beneath the unconformity. This would account for the general absence of deep reflections. It also explains the faint 2-second event observed on Bruny Island. This is equivalent to a depth of about $4 \mathrm{~km}$, the level inferred for the interface between Precambrian units using gravity data.

Figures 6 and 7 also suggest sites where postCambrian veneers might be present but this aspect of the interpretation is most uncertain. No gap in excess of one kilometre has yet been inferred between the nominal base of Truro Tillite and Cambrian or older rocks, and nuch of the apparent gap could be subsumed by false assumptions concerning the amount of tillite in the particular area. It is possible to systematically trace a wedge of Gordon Group from the Picton River toward the Huon River but nowhere else.

The implied limited distribution of Gordon Group materiats west of the Huron River, or as very thin

FIG. 5 - Summary of gravity-magnetic interpretation results: (A) Jurassic dolerite feeders, location and shapes as defined by available data; $(B)$ compilation of all trend information (firm and broken lines represent post-Carboniferous or topographic features; fine lines represent features identified by gravity or magnetic data); (C) combined gravity-magnetic interpretation of depth to top of Tyennan-region-type Precambrian basement; (D) interpretation of depth of base of (?) Cambrian volcanic sequences (all contours in km below sea level). 
$\mathrm{N}$
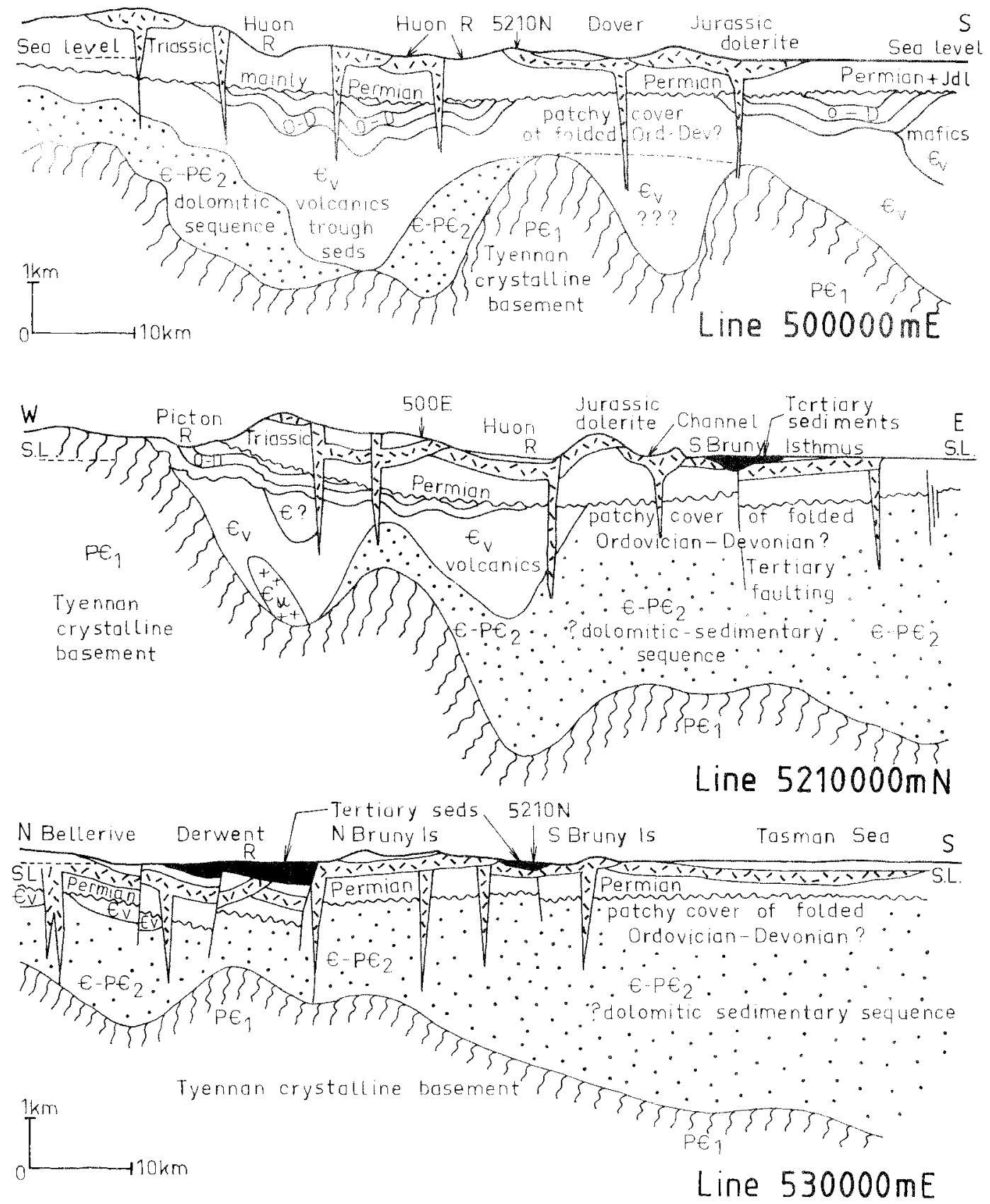

FIG. 6-- Representation of geophysical interpretation as comentional geological sections; symbols as figure 4. Phyllite drilled at Woodbridge is considered representative of E-pE, (Jubilee-region-style Precambrian). 


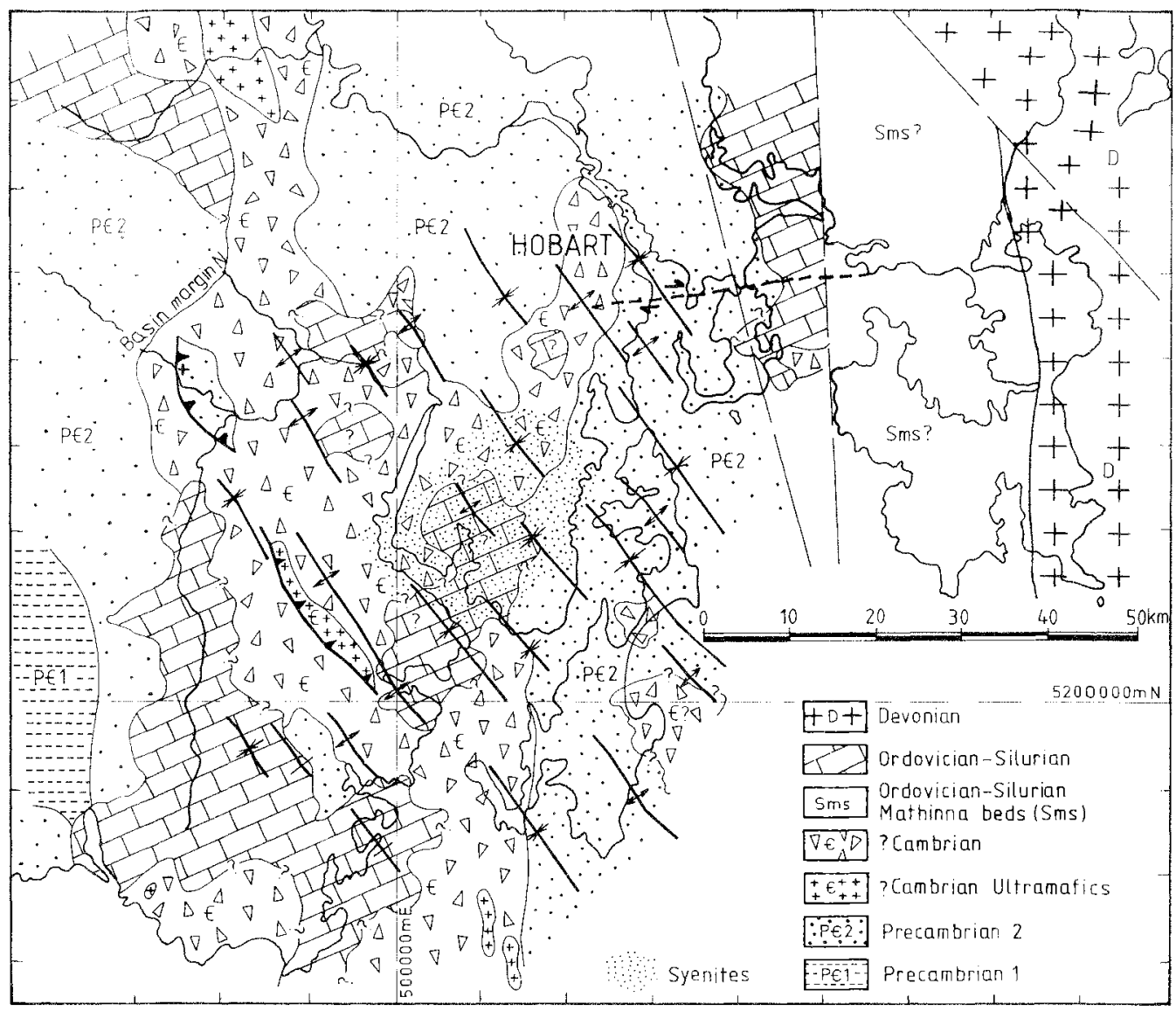

FIG. 7 - Distribution of inferred basement rock types at the base of the Parmeener Supergroup. The distribution of post-Cambrian Palaeozoic units is not well established and the se may be present only as small patches. Possible regional fold trends and thrasts indicated in interpretation are shown.

venecrs elsewhere, would account for the extraordinary bias to ard metamorphic and igneous rocks in the Cart ferous tillites in southeastern Tasmania.

Several aspects of post-Carboniferous structuring and terrain development have long appeared enigmatic. These include the trend changes of the Huon and Derwent estuaries and the Derwent crosscut between New Norfolk and Bridgewater. No obvious post-Carboniferous controls or structures are present. Figure $5 \mathrm{~B}$ shows that such features, and many coastal outlines, reflect basement features. Trends evident in regional gravity and magnetic data delimit major basement boundaries, and these have been impressed or rejuvenated periodically. Many direct correlations are apparent, while other relationships can be inferred. The dextral offset shown in figure 7 near Hobart is an example. This feature corresponds to many cross-trends (fig. 5B) and several Jurassic dislocations lie along it. Tertiary basin trends swing from NW-SE north of it to NE-SW south of it. Basement structural control is indicated.

Dolerite feeders can be associated with the form and changes in marginal gradients of the (?) Cambrian trough where present (fig, 5C, D) and with fracture-trend concentrations elsewhere (fig. 5B). Some major trends identified by all data sets and which imply a substantial ranging source depth, are labelled in figure $5 \mathrm{~B}$. 
Williams (1976) suggested that the possible extension of the Tamar Lineament might occur east of South Am. Gravity and magnetic data in the Storm Bay region do indicate a change in basement composition at the longitude of Sorell. Figure 3 shows that this is not due to the presence of granitoids. The western face of the adamellite complex 1 ies at the longitude of Port Arthur and Dunalley and is marked by $\mathrm{N}-\mathrm{S}$ coastal features. This relationship also suggests continual renewal of structural boundaries. The interpretation (fig. 7) suggests thatnortheast of Sorell the granitoid margin is offset to the northwest. The margin then continues $\mathrm{N}-\mathrm{S}$ through the eastern midlands. The change in basement composition inferred on the eastern side of Storm Bay occurs where the margin in the midlands would occur if projected southward. Since the entire granitoid intrusion pattern indicates fracture control, the original fracture would appear to have been preserved south of Sorell. It is possible that the block between this projection of the granite margin and its actual margin at Port Arthur is composed of Ordovician-Devonian Mathinna Beds and possibly granodiorite, as occurs west of Scottsdale.

\section{ACKNOWLEDGEMENTS}

The writer is grateful to Conga Oil Pty Ltd for the invitation to work with its data and consolidate a basement concept from all sources. Permission to publish the data and the results of interpretation is also acknowledged.

\section{REFERENCES}

AMOCO, 1971: Final report of the Cape Pillar Marine Seismic Survey Tasmania. Tenement Tll P. March 1971. Tasm. Dep. Mines Open File.

Banks, M.R., 1981: Late Palaeozoic tillites of Tasmania. In Hambrey, M.J \& Harland, W.B. (Eds): EARTH'S PRE-PLEISTOCENE GLACIAL RECORD. Cambridge University Press: 495-501.

BMR, 1988: Total magnetic intensity contours Tasmania. Map, In Burrett, C.F. \& Martin, E.L. (Eds): GEOLOGY AND MINERAL RESOURCES OF TASMANIA. Geol. Soc. Aust. Spec. Publ. 15

Bkown, A.V, 1988: Eo-Cambrian-Cambrian. In Burrett, C.F., \& Martin, E.L. (Eds): GEOLOGY AND MINERAL RESOURCES OF TASMANIA. Geol. Soc. Aust. Spec. Publ. 15: 47-83.

Clakke, M.J., 1988: Lower Parmeener Supergroup. In Burrett, C.F. \& Martin, E.L. (Eds): GEOLOGY AND MINERAL RESOURCES OF TASMANIA. Geol. Soc. Aust Spec. Publ. 15: 295-299.

ESSO, 1967: Aeromagnetic survey of fshore Tasmania. EL 17-19/65. Report by Geophysical Ascocides L.td.
Tasm. Dep. Mines Open File.

Everard, G. 1976: Chapel Street bore hole In Leaman. D.E.: HOBART Geol Sum. Tasm Explan. Rep Tasm. Dep. Mines.

Farmer, N., 1985: Kingborough. Geol. Shrv. Tasm. Explan. Rop. Tasm. Dep. Mines.

Farmir, N. \& Clarke, M.J.,1985: A diamond drill hole at Litte Peppermint Bay, Woodbridgs. Unpubl. Rep. Tasm. Dep. Mines 1985/24.

Finney, W.A. \& Sullify, E.P., 1967: Tasmania aeromagnetic survey. Rec. B.M.R. Aust. 1967/19.

Gur.ine. A.B. \& Clarke, M.J., 1984: A diamond drill hole at Eaglebawk Neck, Tasman Peninsula. Unpubl. Rep. Tasm. Dep. Mines 1984/76.

LEAMAN, D.E., 1972; Gravity survey of the Hobart District. Bull. geol. Surv. Tasm. 52.

Leaman. D.E., 1976: Hobart. Geol Sury. Tasm. Explan. Rep. Tasm. Dep. Mines.

LEAman, D.E., 1978: Use of the reflection method in Tasmania. Part 1. Equipment, techniques and problems. Unpubl. Geophys. Spec. Rep. Tasm. Dep. Mines 7.

Leaman, D.E., 1987: Phase 1 Interpretation. Gravity and magnetic data. D'Entrecasteaux Region southern Tasmania. Report for Conga Oil. Tasm. Dep. Mines Open File. $104 \mathrm{pp}$.

LEAMAN, D.E., 1988a: MANTLE-88. Regional gravity field, Tasmania. Mt Read Volcanics Project Rep. Tasm. Dep. Mines.

LEAMAN, D.E., 1988b: Regional evaluation west and north west Tasmania: Precambrian and Lower Palaeozoic structural relationships. Mt Read Volcanics Project Rep. Tasm. Dep. Mines.

LeAmas, D.E. \& NAQvi, 1.H., 1968: The geology and geophysics of the Cygnet District. Bull. geol. Surv. Tasm. 49:1-110.

Leaman, D.E. \& Richardson, R.G., 1981: Fingal Tier seismic reflection traverses 1 and 2. Unpubl. Rep. Tasm. Dep. Mines 1981/6.

Leaman, D.E. \& Richardson, R.G., 1989: Production of a residual gravity field map for Tasmania and some implications. Melbourne Conference volume. Explor. Geophys. 20: 181-184.

Richardson, R.G. \& LEAMAN, D.E, 1987: TASGRAV. The Tasmanian gravity data base. Unpubl. Rep. Tasm. Dep. Mines 1987/2.

SUTHERLAND, F.L., 1976: Cainozoic volcanic rocks. In Leaman, D.E.: HOBART. Geol. Surv. Tasm. Explan. Rep. Tasm. Dep. Mines.

TuRner, N.J., 1988: Precambrian. In Burrett. C.F. \& Martin, E.L. (Eds): GEOLOGY AND MINERAL RESOURCES OF TASMANIA. GeOl. SOC. Aust. Spec. Publ. 15: 5-46.

Wrliams, E., 1976: 1:500,000 Structural Map of PreCarboniferous Rocks of Tasmania. Tasm. Dep. Mines.

(accepted 1 December 1989) 